\title{
Purification of trypsin inhibitor from seeds of Cicer arietinum (L.) and its insecticidal potential against Helicoverpa armigera (Hübner)
}

\section{Meera Nair ${ }^{1 *}$, Sardul Singh Sandhu', Anita Babbar ${ }^{2}$}

'Fungal Biotechnology \& Invertebrate Pathology Laboratory, Department of Biological Sciences, Rani Durgavati University,

Jabalpur, Madhya Pradesh, India.

²Department of Plant Breeding \& Genetics, Jawaharlal Nehru Vishvavidyalaya (J.N.K.V.V.), Adharatal,

Jabalpur, Madhya Pradesh, India.

*Corresponding author: meera.nair3@gmail.com

Received: 27 February 2013; Accepted: 20 June 2013

ABSTRACT: Trypsin inhibitors (TI) have crucial functions in plant defense against pests, and recent studies reveal their diversity in stress response. Disease and herbivore infestations are harmful to plant growth, but the response of TI in Cicer arietinum (L.) in Central India has been less studied. In the present study, we partially characterized the TI from Cicer arietinum (L.) seeds and evaluated its insecticidal potential against Helicoverpa armigera (Hübner). A $20 \mathrm{kDa}$ trypsin inhibitor was purified to homogeneity by ammonium sulfate precipitation and chromatographies with Sephadex G-100 and diethylaminoethyl cellulose (DEAE-cellulose-52) ion-exchange column. $\mathrm{TI}$ assay categorized 17 cultivars in three groups: with high (more than $70 \%$ ), intermediate (16-70\%) and very low (0-15\%) $\mathrm{TI}$ activity. Moreover, results from the TI activity coincided with herbivore attack studies carried out in J.N.K.V.V. fields earlier. Together, our results suggest that the presence of TI triggers a signal that leads the dynamics of stress response and, in turn, regulates pest resistance in plants. Feeding experiments conducted with $5^{\text {th }}$ instar larvae suggested dose-dependent decrease for both the larval weight and the survival of the larva.

KEYWORDS: bioassay, Helicoverpa armigera gut proteinase (HGP), resistant, susceptible, protein.

ABBREVIATIONS: TIA: trypsin inhibitor activity, HGP: Helicoverpa armigera gut proteinase; pNA: para-nitroaniline; $\mathrm{R}_{\mathrm{N}}$ : resistant non-infested cultivars; $\mathrm{S}_{1}$ : susceptible infested cultivars; CaTI: Cicer arietinum trypsin inhibitor; TCA: trichloroacetic acid; BApNA: Na-Benzoyl-D, L-arginine 4-nitroanilide hydrochloride.

\section{INTRODUCTION}

Cicer arietinum is an important self-pollinated diploid crop $2 \mathrm{n}=2 \mathrm{x}=16$ with genome sized approximately 931 Mbp (Arumuganathan and Earle 1991). India is the largest producer of chickpea, contributing with about $66 \%$ of the total global production, followed by Turkey, Pakistan and Mexico (Thangwana and Ogola 2012). It is a major source of protein (12.4-31.5\%), energy, fiber, vitamins, minerals and essential amino acids such as tryptophan and lysine (Maiti 2001).
Helicoverpa armigera Hübner (Lepidoptera: Noctuidae) is a polyphagous pest of 182 plant species across 47 families in the Indian subcontinent, out of which 56 are heavily damaged and 126 are rarely affected. Helicoverpa armigera (Hübner), also known as cotton bollworm or legume pod borer, is one of the most devastating crop pest of Cicer arietinum since it inflicts annual losses of over US\$328 million. Losses caused only by this pest reported up to US\$ 17 million in crops like cotton, pigeon pea, chickpea, groundnut, sorghum, pearl millet, tomato and others 
of economic importance (Chaturvedi 2007). Migration by Helicoverpa armigera is a wide-spread phenomenon and causes major crop losses. As $H$. armigera has high reproductive and damage potentials, their suppression becomes inevitable.

The best counter action to control of $H$. armigera infestation in Cicer arietinum (L.) fields is the use of chemical insecticide and pesticides. But due to the high costs of insecticides, pesticides and their risk for the balance of nature and human health, proteinase inhibitor becomes a defense alternative by creating an insect-resistant plant (Ryan 1990). Plants synthesize proteinase inhibitors, alpha-amylase inhibitors, lectins and chitin binding proteins to resist herbivorous insects, pathogens and wounding (De Leo et al. 2001). Proteinase inhibitors have also been shown to act as a defensive compound against phytophagous insects by the direct assay or expression in transgenic crop plants (Koiwa et al. 1998, Vain et al. 1998). Studies have shown that a major part of Helicoverpa armigera gut proteinase activity can be blocked by soybean kunitz trypsin inhibitor (Johnston et al. 1991, Harsulkar et al. 1999). Numerous insect-feeding bioassays and experiments with transgenic plants have also shown the delayed growth and development of the insect (Koiwa et al. 1998, Parde et al. 2010).

Many studies have indicated the relevance of proteinase inhibitor (trypsin inhibitor) for plant defense. The overexpression of both endogenous and exogenous inhibitors is another option to augment the defense mechanism (Lawrence and Koundal 2005). In addition, certain parameters like viz. insect gut $\mathrm{pH}$, larval developmental stage, concentration of PI and the better understanding of how insects respond and adapt to PIs influence its effectiveness (Dunse and Anderson 2011).

There is a continuous search for new inhibitors that are able to oppose such pest adaptation via antimetabolic activity. Moreover, with genetic engineering replacing one or more PI domains in the multidomain precursor, with PIs tailored w.r.t., gut proteinases of a target insect are also being considered (Ellis and Jones 1998). Thus, the present investigation was focused on the purification and characterization of trypsin inhibitor from the chickpea (CaTIs), the concentration of purified trypsin inhibitor, and the effectiveness under insect gut $\mathrm{pH}$ with its antimetabolite effect on the growth and development of H. armigera.

\section{MATERIALS AND METHODS}

Plant material : Cicer arietinum cultivar seeds (17) were obtained from the Department of Plants Genetics \& Breeding, Jawaharlal Nehru Krishi Vishvavidyalaya (J.N.K.V.V.), Jabalpur, India. Each plant was grown from a single seed, planted in a rectangular and maintained under greenhouse conditions.
Prior to $H$. armigera infestation, studies on all 17 cultivars had been carried out (M. Nair, unpublished results).

Extraction of trypsin inhibitor from seeds of Cicer arietinum (L.) cultivars: Dekernalised Cicer arietinum seeds $(100 \mathrm{~g})$ were crushed, depigmented and defatted with chilled acetone $(300 \mathrm{~mL})$ four to five times, and with $\mathrm{n}$-hexane $(200 \mathrm{~mL})$ twice, respectively. These solvents were filtered and seed powder was recovered after air drying. The resulting flour was suspended in $10 \mathrm{mM}$ phosphate buffer, $\mathrm{pH} 7.2$, at $5^{\circ} \mathrm{C}$ for $6 \mathrm{~h}$ with continuous stirring. After centrifugation at $12,000 \mathrm{xg}$ for $30 \mathrm{~min}$ at $4^{\circ} \mathrm{C}$, crude fraction was used to determine trypsin inhibitor activity via subsequent dot blot assay and proteinase inhibitor activity.

\section{Analysis of trypsin inhibitor by the dot blot method :}

Crude extracts of all 17 cultivars were tested for trypsin inhibitor activity using two natural substrates (casein and gelatin) with trypsin (EC 3.4.21.4) being the enzyme. Gelatin plates were prepared by adding $1 \mathrm{~g}$ of agar, $0.1 \%(\mathrm{w} / \mathrm{v})$ gelatin to autoclaved $100 \mathrm{~mL}$ of $100 \mathrm{mM}$ Tris-HCl buffer ( $\mathrm{pH} 8.0)$ via continuous stirring in a water bath at $80^{\circ} \mathrm{C}$. The mixture was then poured into sterile petri dishes under sterile conditions and solidified. Similarly, casein plates were prepared by adding $1 \mathrm{~g}$ of hammerstein casein to $50 \mathrm{~mL}$ of autoclaved Tris- $\mathrm{HCl}$ buffer (100 mM, pH 8.0). The solution was dissolved in a water bath at $80^{\circ} \mathrm{C}$ with precautionary measures to avoid the coagulation of the casein due to overheating. The solution was then added to $50 \mathrm{~mL}$ of $1 \%(\mathrm{w} / \mathrm{v})$ premelted autoclaved agar in $100 \mathrm{mM}$ Tris-HCl buffer ( $\mathrm{pH}$ 8.0). The resulting mixture was later poured into sterile petri plates and left undisturbed until becoming solid.

Crude extracts of different concentrations (10 to $1000 \mu \mathrm{g}$ ) were pipetted into respective wells with trypsin enzyme as control. The reaction was terminated by the addition of $5 \mathrm{~mL}$ of $5 \% \mathrm{TCA}$, in case of casein, and $2 \% \mathrm{HgCl}_{2}$, in case of gelatin. Observations were recorded for control (where no crude extract was added) and experimental sets. Casein plates were stained with Coomassie Brilliant Blue for $30 \mathrm{~min}$. Protein concentration was estimated by the Lowry method using bovine serum albumin as the standard (Lowry et al. 1951).

Trypsin inhibitor assay : The trypsin inhibitor (TI) activity was assessed by incubating $50 \mu \mathrm{l}$ of crude extract with $20 \mu \mathrm{l}$ of commercial bovine trypsin $\left(1 \mathrm{mg} \mathrm{mL}^{-1}\right)$ and incubating at $37^{\circ} \mathrm{C}$ for $15 \mathrm{~min}$, by adopting the method given by Kakade et al. (1974) and Nagashima et al. (2004). Then, $40 \mu \mathrm{l}$ (from the stock solution of $10 \mathrm{mg} \mathrm{mL}^{-1}$ in Dimethyl Sulfoxide) BApNA was added to the assay solution and the mixture was further incubated at $37^{\circ} \mathrm{C}$ for $30 \mathrm{~min}$. Reaction was terminated by adding $500 \mu \mathrm{l}$ of $10 \%$ glacial acetic acid and the absorbance of the reaction mixture was 
measured at $410 \mathrm{~nm}$ against a reference blank without trypsin and a blank containing crude extract without BApNA in order to subtract the absorbance from the yellow pigment of the crude extract. Trypsin inhibitory activity was measured by obtaining the difference between the enzyme activity in the absence and in the presence of inhibitors.

Purification of trypsin inhibitor : The crude extract was filtered and subsequently saturated with ammonium sulfate in three stages [0 to $40 \%(105.27 \mathrm{~g}), 40$ to $60 \%(58.50 \mathrm{~g})$ and 60 to $90 \%(100.74 \mathrm{~g})]$ to precipitate the protein at $4^{\circ} \mathrm{C}$. After the centrifugation at $12,000 \times \mathrm{g}$ for $30 \mathrm{~min}$ at $4^{\circ} \mathrm{C}$, the resulting precipitate was dissolved in the minimum volume of distilled water ( $\mathrm{pH} 7.5)$ and dialyzed against $3 \times 500 \mathrm{~mL}$ of $10 \mathrm{mM}$ Tris/HCl buffer, $\mathrm{pH}$ 7.5, and loaded on Sephadex G-100 (Pharmacia, Sweden), which was earlier equilibrated with chilled $10 \mathrm{mM}$ Tris/ $\mathrm{HCl}$ buffer, $\mathrm{pH}$ 7.5. When the sample had thoroughly percolated into the column, it was then washed with $10 \mathrm{mM}$ Tris- $\mathrm{HCl}$ buffer ( $\mathrm{pH} 7.8$ ) (five times the column length). Fractions ( $2 \mathrm{~mL}$ each) were collected and tested for protein (using the Lowry method) and trypsin inhibitory activity (using BApNA as substrate).

Active fractions with trypsin inhibitor activity (Fraction A) were further purified by anion exchange chromatography. Active fractions were precipitated with the addition of chilled acetone (in ice cold condition) and centrifuged at 10,000 $\mathrm{x} g$ at $4^{\circ} \mathrm{C}$ for $15 \mathrm{~min}$. Pellets were redissolved in minimum volume of distilled water ( $\mathrm{pH} 7.5)$ and loaded to Diethylaminoethyl cellulose (DEAE-cellulose-52) ion-exchange column, which was pre-equilibrated with $100 \mathrm{~mL}$ of chilled $50 \mathrm{mM}$ Tris/ $\mathrm{HCl}$ buffer, $\mathrm{pH}$ 7.5. Bound proteins were eluted with a linear salt gradient of $0-2 \mathrm{M} \mathrm{NaCl}$. Fractions of $2 \mathrm{~mL}$ were collected and monitored for protein $\left(\mathrm{A}_{280}\right)$ and trypsin inhibitor activity, as aforementioned.

\section{Electrophoretic analysis of trypsin inhibitor :} Electrophoretic analysis was performed in two stages: one undergoing $12 \%(\mathrm{w} / \mathrm{v})$ SDS polyacrylamide gel and another gel containing $0.1 \%$ gelatin $(\mathrm{w} / \mathrm{v})$ to determine the trypsin inhibitor. Gel was run at a constant voltage of $50 \mathrm{~V}$ at $4^{\circ} \mathrm{C}$ in Tris Glycine-SDS (TGS) buffer (25 mM Tris/HCl pH 8.8, $192 \mathrm{mM}$ glycine and $0.1 \%(\mathrm{w} / \mathrm{v})$ SDS). Activity staining was carried out according to the protocol followed by Mulimani et al. (2002). Molecular mass of the protein was determined by comparing them with soybean trypsin inhibitor (Calbiochem ${ }^{\circledR}$, USA) as standards, and the protein molecular weight marker.

\section{Extraction of proteinase from larvae of Helicoverpa} armigera (Hüber) : For extraction of proteinase, fifth instar
Helicoverpa armigera larvae were collected from chickpea fields of J.N.K.V.V., Jabalpur. Mid-guts of $H$. armigera were isolated by dissecting the larvae and mixing the gut tissue with three volumes of chilled 0.1 M glycine- $\mathrm{NaOH}$ buffer, $\mathrm{pH}$ 10.0. Gut luminal contents were allowed to stand for $15 \mathrm{~min}$ centrifuged at $10,000 \mathrm{x} g$ for $10 \mathrm{~min}$ at $4^{\circ} \mathrm{C}$ analyzed for protein content and proteinase activity.

\section{Determination of proteinase activity in Helicoverpa} armigera gut proteinase (HGP) : Total gut proteinase activity was measured by performing the dot blot assay and proteinase activity using casein and BApNA without trypsin inhibitor, according to the protocol by Erlanger et al. (1964) with some modifications.

In vitro activity of CaTI in HGP : The experiment was carried out in three slots. Firstly, the activity of trypsin inhibitor towards the midgut of Helicoverpa armigera larvae (HGP) at $\mathrm{pH}$ 7.8 and 10 was determined. Secondly, the trypsin inhibitory activity using bovine trypsin (BT) and HGP was compared to determine their proteolytic activity, and thirdly, the trypsin inhibitor activity of a crude extract, fraction A (gel filtrate fraction) and anion exchange fractions were determined with bovine trypsin and HGP as an enzyme. BApNA was used as a substrate at the standard conditions described earlier, in order to test the in vitro activity of CaTI on HGP.

In vivo activity of trypsin inhibitor (TI) against $\boldsymbol{H}$. armigera : Bioassays were conducted by feeding $H$. armigera larvae on chickpea TIs incorporated to an artificial diet at $28^{\circ} \mathrm{C}$ and 55\% stable humidity (Giri and Kachole 1998). Bioassays were conducted in a $40 \mathrm{~mL}$ artificial diet $[140 \mathrm{~g}$ of chickpea seed meal, $14 \mathrm{~g}$ of yeast extract, $0.4 \mathrm{~g}$ of Bavistin (BASF, Mumbai), $0.2 \mathrm{~mL}$ of formalin, $4.3 \mathrm{~g}$ of ascorbic acid, $1.3 \mathrm{~g}$ of sorbic acid, $2.6 \mathrm{~g}$ of methyl benzoate, $0.5 \mathrm{~g}$ of tetracycline, one tablet of vitamin-B complex and two drops of vitamin E], which was added to $450 \mathrm{~mL}$ of distilled water. To this mixture, $17 \mathrm{~g}$ of agar dissolved in $500 \mathrm{~mL}$ of water $\left(50-60^{\circ} \mathrm{C}\right)$ was added, mixed and poured into trays which were cut into cubes $(2 \mathrm{~g})$ and used in feeding experiments. Trypsin inhibitor was incorporated to the diet at concentrations of 10,100 and $500 \mu \mathrm{M}$, and weight was monitored in intervals of $2 \mathrm{~d}$ until pupation. In negative controls, distilled water was added with no chickpea TIs added to the artificial diet.

\section{RESULTS}

Cicer arietinum (L.) trypsin inhibitor was purified to homogeneity in four steps: by the preliminary identification via the dot blot assay, trypsin inhibitor assay, ammonium 
sulfate precipitation, Sephadex G-100, and anion exchange chromatography (DEAE-cellulose-52 column). In the present study, trypsin inhibitor activity was detected in all 17 Cicer arietinum (L.) cultivars' crude extract by both the dot blot and the proteinase inhibitor assays.

Dot blot Assay : In the dot blot assay, ten cultivars (JG-63, JG 99-115, ICCV-2, KAK-2, JG 2004-944, JG 2003-108, JG 200112, JGK-334, JGK-333, JGK-8) produced no halo zone, whereas seven cultivars (C-134, JG-16, ICC-11550, JGK-1, JGK-7, JGK313, JGK-3) showed complete halo zone as shown in Figure 1 and Table 1 . These results were compared to infestation trials held up earlier in J.N.K.V.V. fields (M. Nair, unpublished results), which completely showed the direct variation between $H$. armigera infested and non-infested cultivars, thereby creating two groups: (1.) Non-infested cultivars as being resistant $\left(\mathrm{R}_{\mathrm{N}}\right)$, and (2.) Infested cultivars as being susceptible $\left(\mathrm{S}_{\mathrm{I}}\right)$.

Trypsin Inhibitor Assay : Results of trypsin inhibitor activity (TIA) were similar to those in the dot blot assay, in which trypsin inhibitor activity was found to be the lowest in seven cultivars (JGK-313, JGK-1, JGK-3, JGK-7, JG-16, C-134, ICC-11550 and JGK-334) and the highest in ten cultivars (JG-63, JG 99-115, ICCV-2, KAK-2, JGK-333, JG 2004-944, JG 2003-108, JGK-8 and JG 2001-12), which have been earlier categorized as being susceptible infested $\left(\mathrm{S}_{\mathrm{I}}\right)$ and resistant non-infested $\left(\mathrm{R}_{\mathrm{NI}}\right)$ cultivars in infestation studies as described in Table 3.

Trypsin proteinase activity using both natural (casein) and synthetic substrate (BApNA), without inhibitor, was $227.66 \pm 0.5 \mathrm{nmol} \mathrm{tyr} \mathrm{min}^{-1} \mathrm{mg}^{-1}$ protein and $172.01 \pm 0.5 \mu \mathrm{mol} p \mathrm{NA} \mathrm{min}{ }^{-1} \mathrm{mg}^{-1}$ protein, respectively. The result of TIA indicated the inhibition in trypsin activity as the release of the $p \mathrm{NA}$ [ $p$-nitroaniline] product. In case of $\mathrm{R}_{\mathrm{NI}}$ cultivars, the release of $p \mathrm{NA}$ was very low, being substantially higher in $S_{I}$ cultivars in relation to control, in which trypsin enzyme activity was observed to be $100 \%$.

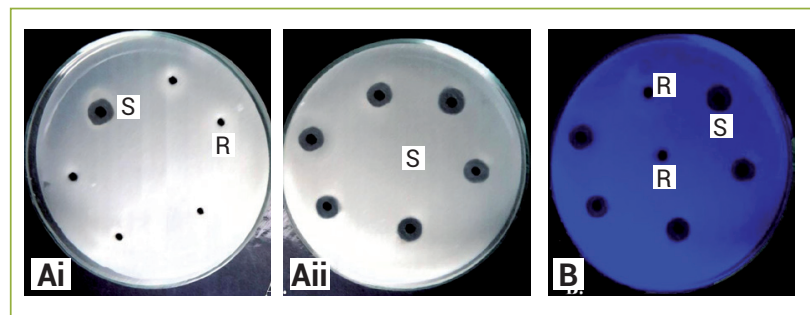

Figure 1. Dot Blot assay using crude extract of Cicer aritienum (L.) cultivars. (Ai,ii) No halo zone was found in $\mathrm{R}_{\mathrm{NI}}$ (JG-63, JG 99-115, JG 2003-108, JG 2001-12, JGK-8) with respect to SI (C-134, JG-16, ICC-11550, JGK-1, JGK-7, JGK 313, JGK-3) cultivars which showed clear halo zone in gelatin amended plates. (B) Casein amended plates were stained with Coomassie Brilliant Blue stain for $30 \mathrm{~min}$.
In resistant non-infested plants $\left(\mathrm{R}_{\mathrm{N}}\right)$, the trypsin inhibitory activity was higher with increased inhibitor concentration, or it was in intermediate concentrations, whereas no inhibition was seen in susceptible infested cultivars $\left(\mathrm{S}_{\mathrm{I}}\right)$. These data are shown in Table 2

Trypsin inhibition percentage varied from $0-99 \%$ and 10-99.4\% using casein and BApNA, respectively. The low percentage of inhibition (0-15\%) was due to the absence of trypsin inhibitor in crude extract, whereas in $\mathrm{R}_{\mathrm{NI}}$ plants the hydrolysis of casein and BApNA was maximally inhibited, thereby showing a $99.9 \%$ inhibition. These data are shown in Table 2. Cultivars were therefore ranked into three classes according to trypsin inhibition percentage using BA $p$ NA results:

1. Low TIA group of cultivars, from $0-15 \%$ of inhibition

2. Intermediate group of cultivars, from $16-70 \%$

3. A high TIA group of cultivars, higher than $70 \%$

Cultivars (i.e. JGK-1, JGK-7, JGK-313) with intermediate values were also grouped into resistant $\left(\mathrm{R}_{\mathrm{NI}}\right)$ ones, as shown in Table 3.

\section{Purification of Cicer arietinum Trypsin Inhibitor} (CaTI) : JG 2001-12 indicated a 99.9\% trypsin inhibitory activity, as shown in Table 2, hence it was further used for purification, in vitro and in vivo studies against $H$. armigera. Trypsin inhibitor was purified to homogeneity with 65.4 fold purification using ammonium fractionation and ion exchange

Table 1. Dot Blot Assay

\begin{tabular}{|c|c|c|c|}
\hline Cultivars & Halo zone & Trypsin Inhibitor & $\begin{array}{l}\text { Infestation } \\
\text { studies }\end{array}$ \\
\hline$C-134$ & - & Absent & $S_{1}$ \\
\hline JG-16 & - & Absent & $\mathrm{S}_{1}$ \\
\hline JG-63 & + & Present & $\mathrm{R}_{\mathrm{NI}}$ \\
\hline JG 99-115 & + & Present & $\mathrm{R}_{\mathrm{NI}}$ \\
\hline JG 2004-944 & + & Present & $\mathrm{R}_{\mathrm{N1}}$ \\
\hline JG 2003-108 & + & Present & $\mathrm{R}_{\mathrm{N1}}$ \\
\hline JG 2001-12 & + & Present & $\mathrm{R}_{\mathrm{NI}}$ \\
\hline ICC-11550 & - & Absent & $S_{1}$ \\
\hline JGK-1 & - & Absent & $\mathrm{S}_{1}$ \\
\hline JGK-3 & - & Absent & $S_{1}$ \\
\hline JGK-8 & + & Present & $\mathrm{R}_{\mathrm{NI}}$ \\
\hline JGK-7 & - & Absent & $\mathrm{S}_{1}$ \\
\hline JGK-334 & + & Present & $\mathrm{R}_{\mathrm{NI}}$ \\
\hline JGK-333 & + & Present & $\mathrm{R}_{\mathrm{NI}}$ \\
\hline JGK-313 & - & Absent & $\mathrm{S}_{1}$ \\
\hline KAK-2 & + & Present & $\mathrm{R}_{\mathrm{NI}}$ \\
\hline ICCV-2 & + & Present & $\mathrm{R}_{\mathrm{NI}}$ \\
\hline
\end{tabular}

$\mathrm{R}_{\mathrm{N}}$ : Cultivar Resistant to Helicoverpa armigera infestation; $\mathrm{S}_{\mathrm{i}}$ : Cultivar susceptible to Helicoverpa armigera infestation, per infestation studies. 
chromatography where trypsin inhibitor was eluted, using a $\mathrm{NaCl}$ gradient ( 0 to $2 \mathrm{M}$ ) as shown in Figure 2B.

The active fractions of anion exchange peak were pooled, concentrated and analyzed later for TIA. This protocol yielded a purified trypsin inhibitor, with $140 \mu \mathrm{M} p \mathrm{NA} \mathrm{min}{ }^{-1} \mathrm{mg}^{-1}$ specific activity, and low protein content, of $0.1 \mathrm{mg}$. The data in Table 4 showed an overall 65.4 fold increase in purificarion fold specific activity with $10 \%$ activity yield. The purity of the protein was analyzed by SDS-PAGE, which showed a single thick polypeptide band with molecular mass of approximately $20 \mathrm{kDa}$. The molecular mass was apparently homogenous to the standard molecular weight marker and soybean trypsin inhibitor, thus indicating its purity. The presence of an activity band in reverse zymography gel at the position corresponding to the protein band in SDS-PAGE confirmed the protein band as a trypsin inhibitor; these data are shown in Figure 3A and 3B.

Proteolytic activity of HGP extract : Proteolytic activity of HGP was $148.3 \mathrm{nmol} \mathrm{min} \mathrm{mg}^{-1}$ protein using casein as the natural substrate and $390 \pm 0.5 \mathrm{nmol} \mathrm{min}{ }^{-1} \mathrm{mg}^{-1}$ protein using BApNA as substrate. HGP extracts equivalent to $40 \mu \mathrm{g}$ showed halo zones in the dot blot assay, indicating its proteinase activity as shown in Figure 4 and Table 5.

Effect of CaTI on HGP extract : Inhibition assays using HGP extract and purified TI from Cicer arietinum (CaTI) demonstrated inhibition of HGP at both $\mathrm{pH} 7.8$ and 10 . A $45-50 \%$ inhibition of the HGP activity at $\mathrm{pH} 7.8$ and

Table 2. Trypsin activity and Trypsin Inhibition (\%) of crude extracts in different cultivars of Cicer arietinum (L.)

\begin{tabular}{|c|c|c|c|c|c|}
\hline \multirow[b]{2}{*}{ Addition } & \multicolumn{2}{|c|}{ Trypsin Activity } & \multicolumn{3}{|c|}{ Trypsin Inhibition (\%) } \\
\hline & Casein & BApNA & Casein & BApNA & \\
\hline Cultivar & nmol tyr $\mathrm{min}^{-1} \mathrm{mg}^{-1}$ protein & $\mu \mathrm{mol}$ pNA $\mathrm{min}^{-1} \mathrm{mg}^{-1}$ protein & $\begin{array}{c}\text { Trypsin } \\
\text { Inhibition (\%) }\end{array}$ & $\begin{array}{c}\text { Trypsin } \\
\text { Inhibition (\%) }\end{array}$ & TIA Group* \\
\hline None (control) & $227.6 \pm 0.5$ & $172.01 \pm 0.5$ & 0 & 0 & - \\
\hline \multicolumn{6}{|c|}{ Crude extract } \\
\hline C-134 & $209 \pm 5.7$ & $154.2 \pm 0.3$ & 9.0 & 10.0 & Low \\
\hline JG-16 & $200 \pm 0.5$ & $145.2 \pm 0.3$ & 12.0 & 15.5 & Low \\
\hline JG-63 & $4.2 \pm 0.2$ & $2.2 \pm 0.3$ & 98.0 & 98.0 & High \\
\hline JG 99-115 & $3.6 \pm 0.1$ & $1.4 \pm 0.3$ & 98.0 & 99.0 & High \\
\hline JG 2004-944 & $7.0 \pm 0.2$ & $2.2 \pm 0.3$ & 96.0 & 98.7 & High \\
\hline JG 2003-108 & $5.2 \pm 0.2$ & $3.2 \pm 0.3$ & 97.7 & 98.1 & High \\
\hline JG 2001-12 & $0.7 \pm 0.4$ & $1.0 \pm 0.3$ & 99.0 & 99.4 & High \\
\hline ICC-11550 & $197 \pm 0.2$ & $150.2 \pm 0.3$ & 13.0 & 12.8 & Low \\
\hline JGK-1 & $199 \pm 0.2$ & $144.2 \pm 0.3$ & 12.0 & 16.3 & Intermediate \\
\hline JGK-3 & $197 \pm 0.2$ & $153.2 \pm 0.3$ & 13.0 & 11.1 & Low \\
\hline JGK-8 & $4.7 \pm 0.2$ & $3.2 \pm 0.3$ & 97.9 & 98.1 & High \\
\hline JGK-7 & $200 \pm 0.2$ & $134.2 \pm 0.3$ & 12.9 & 21.9 & Intermediate \\
\hline JGK-334 & $2.4 \pm 0.2$ & $2.2 \pm 0.3$ & 98.0 & 98.7 & High \\
\hline JGK-333 & $3.7 \pm 0.2$ & $3.2 \pm 0.3$ & 98.0 & 98.1 & High \\
\hline JGK-313 & $201 \pm 0.2$ & $124.2 \pm 0.3$ & 11.7 & 27.7 & Intermediate \\
\hline KAK-2 & $2.3 \pm 0.2$ & $3.2 \pm 0.3$ & 98.0 & 98.1 & High \\
\hline ICCV-2 & $4.2 \pm 0.2$ & $5.2 \pm 0.3$ & 98.0 & 96.0 & High \\
\hline
\end{tabular}

TIA group = Classes of trypsin inhibitory activity .

Table 3. Seventeen cultivars of Cicer arietinum (L.) grouped into two TIA groups

Name of Cultivars TIA units

higher than $70 \%$.

JG-63, JG 99-115, ICCV-2, KAK-2, JG 2004-944, JG 2003-108, JG 2001-12

JGK-334, JGK-333, JGK-8

$16-70 \%$

$0-15 \%$

C-134, JG-16, ICC-11550, JGK-1, JGK-7, JGK-313, JGK-3

$\mathrm{R}_{\mathrm{N}}$ : Cultivar Resistant to Helicoverpa armigera infestation; $\mathrm{S}_{1}$ : Cultivar susceptible to Helicoverpa armigera infestation

\section{Result of Infestation studies}

RESISTANT $\left(\mathrm{R}_{\mathrm{NI}}\right)$ 
$30-35 \%$ inhibition at $\mathrm{pH} 10.0$, respectively, were observed. This repression in the proteolytic activity of HGP was due to the presence of CaTI as compared to control (where no CaTI was added), in which the activity was found to be $100 \%$, as demonstrated in Table 6. Figure 5 shows the decreased proteolytic activity of bovine trypsin (BT) and HGP in the presence of CaTI. A close examination revealed that JG
2001-12 cultivar fractions at different purification stages showed an increased inhibitory activity against HGP, as shown in Table 7. It was also observed that, with further purification steps, the inhibitory activity increased as anion exchange fraction exhibited $66.34 \pm 5.66 \mu \mathrm{mol} p \mathrm{NA} \mathrm{min}{ }^{-1} \mathrm{mg}^{-1}$ protein inhibition towards HGP w.r.t. crude extracts and Fraction A (gel filtrate pooled fraction) of gel filtration.

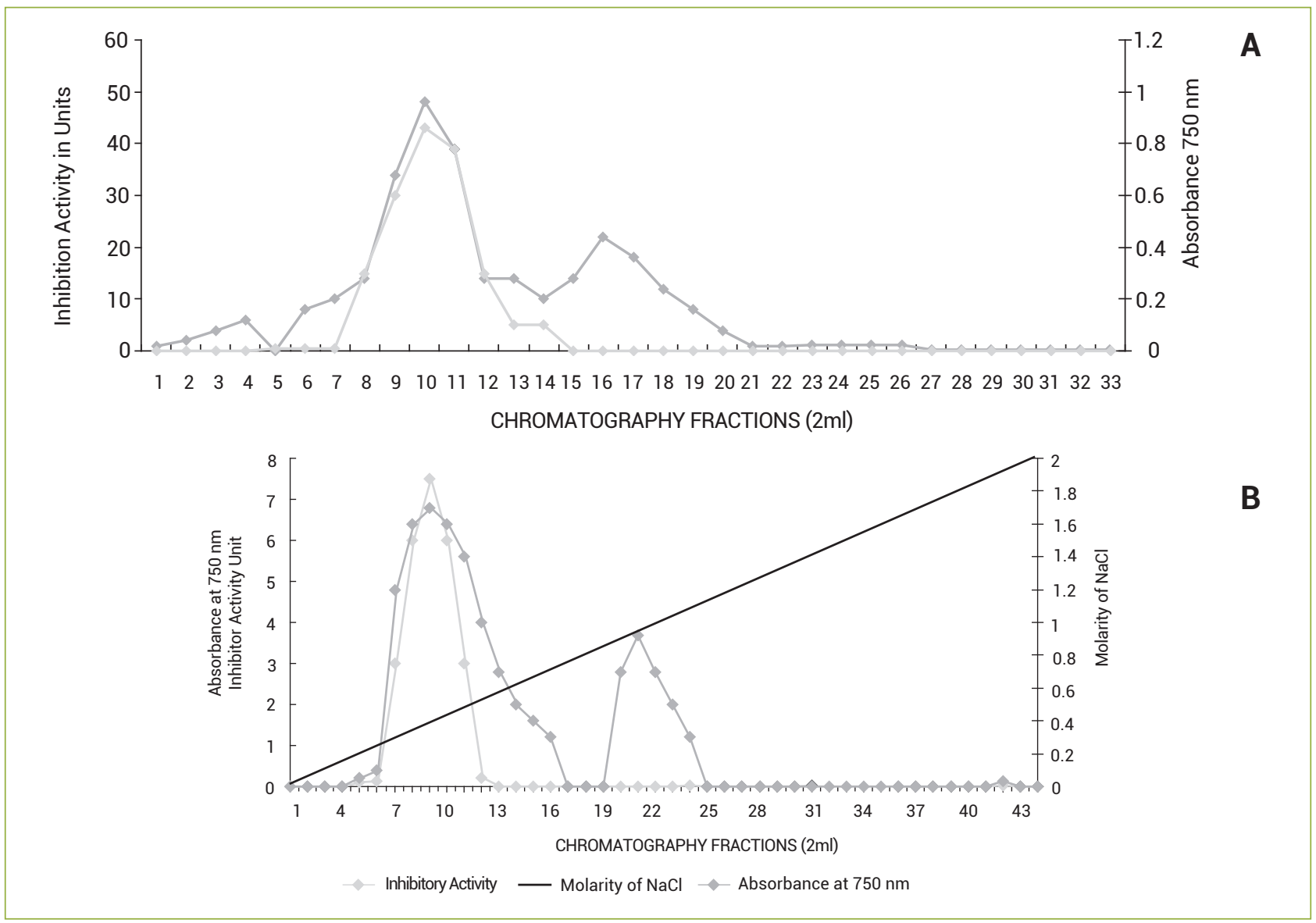

Figure 2. Elution profile of $40-60 \%$ ammonium sulfate-precipitated protein loaded onto a gel filtration column (Sephadex G-100). The protein was eluted out with $10 \mathrm{mM}$ Tris- $\mathrm{HCl}$ buffer (pH 7.8). $2 \mathrm{~mL}$ fractions were collected and analyzed for their inhibitory activity using proteinase inhibitor assay and synthetic substrates (A). Elution profile of the trypsin inhibitor during DEAE-cellulose anion exchange chromatography (B).

Table 4. Extraction Profile for Trypsin Inhibitor from the JG 2001-12 cultivar

\begin{tabular}{|c|c|c|c|c|c|c|c|}
\hline Sample & $\begin{array}{l}\text { Protein } \\
\left(\mathrm{mg} \mathrm{m}^{-1}\right)\end{array}$ & $\begin{array}{l}\text { Total protein } \\
(\mathbf{m g})\end{array}$ & $\begin{array}{l}\text { Total activity } \\
\left(\mu \mathrm{M} \text { pNA } \text { min }^{-1}\right)\end{array}$ & $\begin{array}{c}\text { Specific Activity } \\
\left(\mu \mathrm{M} \text { pNA min } \mathbf{m g}^{-1} \mathrm{mg}^{-1}\right)\end{array}$ & $\begin{array}{l}\text { Trypsin } \\
\text { Inhibition* }\end{array}$ & Yield & $\begin{array}{l}\text { Purification } \\
\text { Fold }\end{array}$ \\
\hline Crude Extract & 8.6 & 258.0 & 20 & 2.32 & 44.5 & 100 & 1.0 \\
\hline $\begin{array}{l}40-60 \% \\
\text { ammonium sulfate }\end{array}$ & 7.8 & 19.6 & 19 & 2.42 & 47.3 & 95 & 12.4 \\
\hline Dialysis & 5.0 & 14.0 & 17 & 3.40 & 52.7 & 85 & 55.1 \\
\hline Sephadex G-100 & 3.6 & 9.0 & 5 & 72.54 & 86.7 & 25 & 57.1 \\
\hline $\begin{array}{l}\text { DEAE-cellulose- } 52 \\
\text { column }\end{array}$ & 0.2 & 0.1 & 2 & 140.00 & 94.4 & 10 & 65.4 \\
\hline
\end{tabular}

*The obtained values were compared with control, in which trypsin inhibitor was replaced with $0.1 \mathrm{M} \mathrm{Tris/HCl} \mathrm{buffer,} \mathrm{pH} 7.5$. Trypsin inhibition was carried out after each step of extraction. 

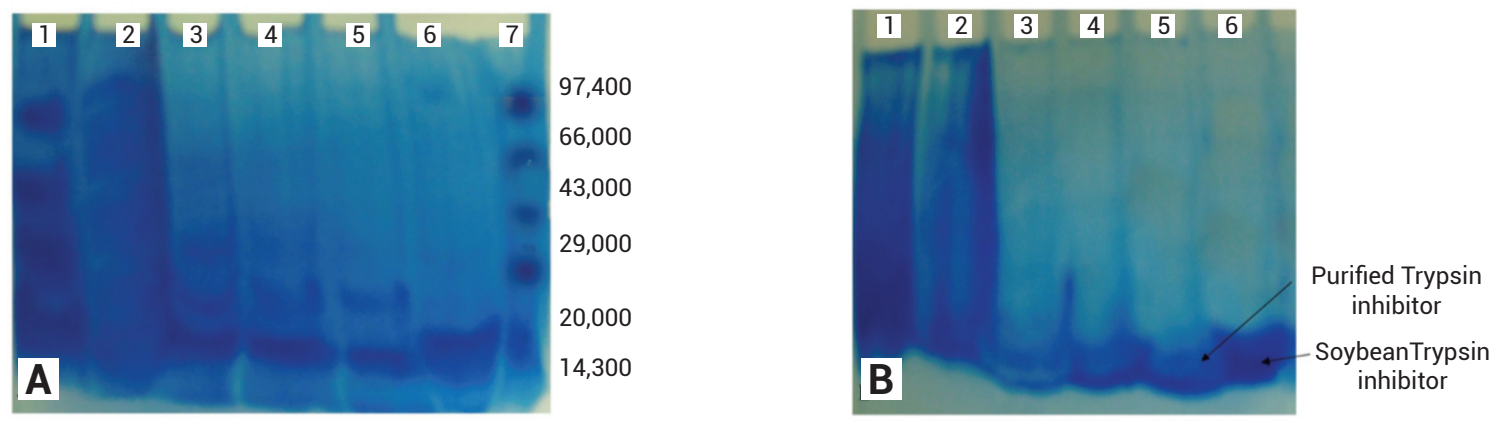

Figure 3. SDS-PAGE of trypsin inhibitor. The samples were mixed with the tracking dye containing bromophenol blue and SDS. Lane 1 Crude Extract Lane 2 40-60\% ammonium sulfate cut off, Lane 3 Fraction 9, Lane 4 Fraction 10, Lane 5 Fraction 11, Lane 6 purified trypsin inhibitor after anion exchange column chromatography, Lane 7 Molecular weight marker (A). Reverse zymography of trypsin inhibitor. Lane 1, Crude Extract, Lane 2 40-60\% ammonium sulfate cut off, Lane 3 Fraction 9, Lane 4 gel filtration Fraction, Lane 5 purified trypsin inhibitor after anion exchange column chromatography, Lane 6 Standard soybean trypsin inhibitor (Sigma) (B).

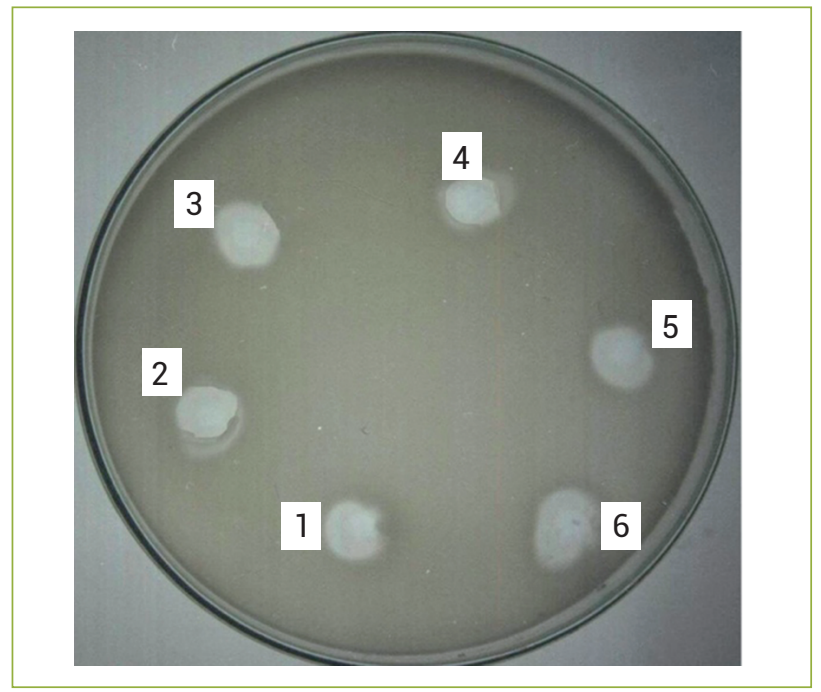

Figure 4. Dot Blot assay showing proteolytic activity of Helicoverpa armigera gut proteinases (HGP). Halo zone was achieved in gelatin amended plates subjected to HGP extract $(1-40 \mu \mathrm{g}, 2-50 \mu \mathrm{g}$, $3-60 \mu \mathrm{g}, 4-70 \mu \mathrm{g}, 5-80 \mu \mathrm{g}, 6-90 \mu \mathrm{g})$.

\section{Effects of ingestion of CaTI on larval digestive}

proteases : A reduction in weight gain among the fifth instar larvae fed on CaTI supplemented diet was observed, thus indicating an in vivo effect on endogenous protease activity of $H$. armigera. At low concentration $(10 \mu \mathrm{M})$, no drastic weight loss was observed, whereas at $100 \mu \mathrm{M}$ and $500 \mu \mathrm{M}$, a significant reduction in weight was observed in comparison to control. The presence of $500 \mu \mathrm{M}$ of CaTI in the diet caused several deleterious effects, thus instigating death. As the concentration of trypsin inhibitor increased, the weight of larvae decreased, pointing to a trivial effect of trypsin inhibitor on the growth and development of H. armigera insect, as shown in Figure 6. The increased
Table 5. Gut proteinase activity of Helicoverpa armigera larvae using natural and synthetic substrates

\begin{tabular}{lcc}
\multirow{2}{*}{ Addition } & Protease activity $\left[\mathrm{nmol} \mathrm{min}^{-1}\left(\mathrm{mg}^{2}\right.\right.$ protein) $\left.{ }^{-1}\right]$ \\
\cline { 2 - 3 } HGP extract & Casein & BApNA \\
\hline
\end{tabular}

Table 6. Proteolytic assays of midgut extract from Helicoverpa armigera larvae with $\mathrm{CaTI}$ at two different $\mathrm{pHs}(7.8$ and 10) and at a constant temperature of $25^{\circ} \mathrm{C}$. Activity is presented as the percentage of the control activity

\begin{tabular}{lcccc} 
& \multicolumn{4}{c}{ Inhibition Percentage (\%) } \\
\cline { 2 - 5 } Treatments & \multicolumn{3}{c}{ Casein } & \multicolumn{2}{c}{ BApNA } \\
\cline { 2 - 5 } Control & 100 & 100 & 100 & 100 \\
\hline CaTI + HGP & 45 & 30 & 50 & 35 \\
\hline
\end{tabular}

CaTI: Cicer arietinum Trypsin inhibitor; HGP. Helicoverpa armigera gut proteinases

Table 7. Trypsin Inhibitor activity of JG 2001-12 cultivar in the midgut protease of Helicoverpa armigera (HGP)

\begin{tabular}{lcc} 
Treatments & $\begin{array}{c}\text { Trypsin Inhibitory } \\
\text { Activity TIA } \text { mg }^{-1} \\
\text { protein }\end{array}$ & $\begin{array}{c}\text { Inhibition of } \\
\text { Helicoverpa Gut } \\
\text { Proteinase }\end{array}$ \\
\cline { 2 - 3 } & \multicolumn{1}{c}{ umol pNA min $^{-1} \mathrm{mg}^{-1}$ protein } \\
\hline $\begin{array}{l}\text { Crude } \\
\text { extract of } \\
\text { JG } 2001-\end{array}$ & $8.71 \pm 1.21$ & $28.56 \pm 1.32$ \\
12 & & \\
\hline $\begin{array}{l}\text { Fraction A } \\
\text { Anion } \\
\text { Exchange }\end{array}$ & $11.36 \pm 3.62$ & $35.71 \pm 4.09$ \\
\hline Fraction & $39.47 \pm 1.91$ & $66.34 \pm 5.66$ \\
\hline
\end{tabular}


concentration also showed abnormality and subsequent death of the larvae. Tryptic activities in the midgut from $5^{\text {th }}$ instar larvae reared on artificial diets containing CaTI altered food accumulation wich led to decrease in weight, leading to growth retardation. It indicated a possible response of starvation in these instars, compared with control.

\section{DISCUSSION}

In this communication, we have isolated CaTI from resistant cultivar, JG 2001-12, which is significantly at par with that obtained from Vigna mungo and Derris trifoliate (Bhattacharyya and Babu 2009, Prasad et al. 2010).

\section{Purification and biochemical activity of CaTI :}

C. arietinum (chickpea) seeds are known to contain

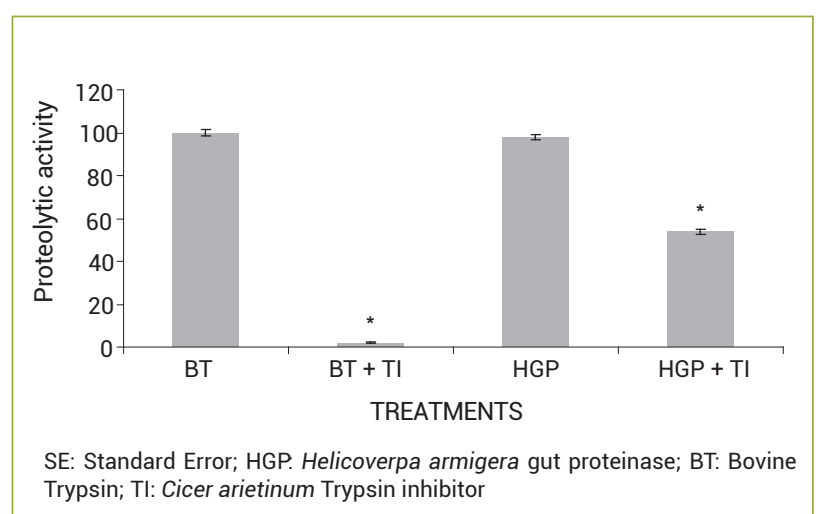

Figure 5. Inhibitory activity of CaTI towards bovine trypsin and proteinases from midgut of Helicoverpa armigera. Values are expressed as mean $\pm S M(n=6)$. Bars with asterisks are significantly different $(p>0.05)$. inhibitors of proteases, and their properties have been studied (Belew and Eaker 1976, Smirnoff et al. 1979, Jibson et al. 1981, Sastry and Murray 1987, Saini et al. 1992, Harsulkar et al. 1997). The screening of 17 cultivars was firstly carried out using the dot blot technique, which provided a direct method for screening trypsin inhibitor protein in crude extracts of various cultivars, whereas the proteinase inhibition assay resulted in a quantitative amount of trypsin inhibitor in these cultivars. H. armigera infestation studies on the fields provided a connection between pest resistance and the presence of trypsin inhibitor, as studies confirmed the idea that inhibitors of serine proteinase interfere with the digestive processes of insects (Rai et al. 2008, Valueva et al. 2012).

The purification of CaTI was carried out using ammonium sulfate precipitation and subsequent dialysis. Preliminary and subsequent assays to determine CaTI confirmed the presence of trypsin inhibitor in JG 2001-12. BApNA and casein substrates provided quantitative data regarding the presence and absence of CaTI in cultivars. Gel filtration chromatography and anion exchange chromatography purified trypsin inhibitor from JG 2001-12 cultivar was found to be $0.45 \mathrm{~g}$ of trypsin inhibitor per kilogram. Further purification steps, using reverse zymography confirmed the presence of trypsin inhibitor in $\mathrm{R}_{\mathrm{NI}}$ cultivar viz. JG 2001-12, where an inhibitor of $20 \mathrm{kDa}$ was determined by SDS-PAGE and reverse zymography. Sharma and Suresh (2011) purified an $18 \mathrm{kDa}$ Kunitz-type trypsin inhibitor protein (CPTI) from chickpea seeds. On the contrary, Srinivasan et al. (2005) identified and purified a low expressing proteinase inhibitor (PI), different from the Bowman-Birk inhibitors from chickpea seeds.

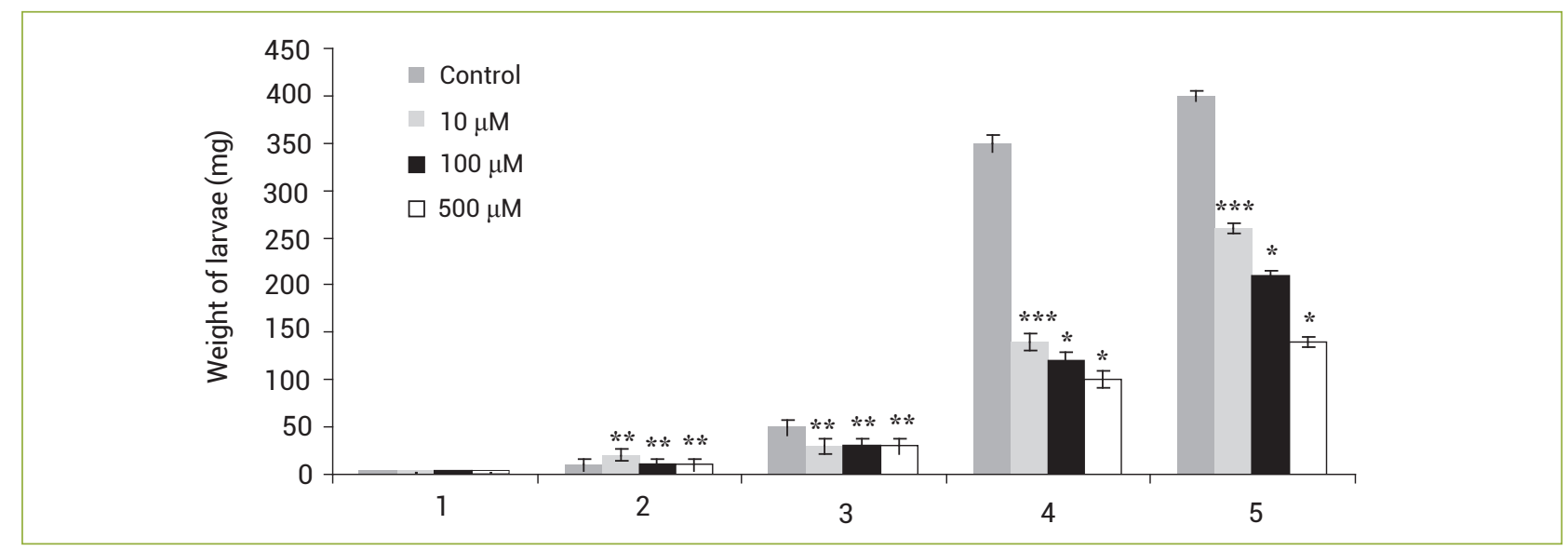

Figure 6. Dose dependent effect of CaTI on the growth and digestive physiology of larval Helicoverpa armigera. Each measurement was done in triplicate. Vertical lines represent the confidence intervals $(n=10)$. Significant difference at $* p<0.05$, significant difference at $* * p<0.01$ and significant difference at $* * * p<0.001$ when compared between the control and inhibitor fed diet. 
Resistance due to trypsin inhibitor : Total gut proteinase activity was determined by both the dot blot assay and the proteinase inhibitor assay, in which the proteolytic activity of HGP was determined. The results were in accordance with those obtained by Giri et al. (1998) and Harsulkar et al. (1998).

Inhibition assays using HGP extract and CaTI were also studied at $\mathrm{pH} 7.8$ and $\mathrm{pH} 10$, because two groups of proteinases showing activity at specific $\mathrm{pHs}$ were identified earlier in HGP complement (Harsulkar et al. 1998). A 45-50\% inhibition of the HGP activity at $\mathrm{pH}$ 7.8 and a $30-35 \%$ inhibition at $\mathrm{pH} 10.0$, respectively, was noticed indicating the stable existence of a distinct class of inhibitors that does have inhibitory activity against HGP, even at low levels, these data are shown in Table 6. The study was further extended to assess purified CaTI against bovine trypsin and HGP, in which a considerably lower proteolytic activity was seen in treatments, thus indicating a single inhibitory site for trypsin and trypsinlike enzymes (Srinivasan et al. 2005). Furthermore, in vitro inhibitory activity of CaTI at different purification levels increased with more purification. Similar results were observed in oryzacystatin (OCI) and Bowman-Birk inhibitors against gut proteinase from Phaedon cochleariae (F.) (Girard et al. 1998).

It was a matter of interest to examine the effect of CaTI ingestion on larval digestive proteases, since preliminary in vitro studies showed inhibition in proteolytic activity at the presence of both bovine trypsin and HGP. The $5^{\text {th }}$ instar larvae reared on a diet containing CaTI showed decreased trypsin proteinase activities of the midgut, as confirmed by the trypsin inhibitor assay, suggesting that the toxic effect of the inhibitor complicates its digestion activity by blocking the enzymes involved in digestion. Lee et al. (1999) reported the inhibitory effect of soybean trypsin inhibitor (SBTI) gene on the brown plant hopper in transgenic rice plants. Similarly, SKTI (soybean trypsin inhibitor) and CpTI (cow pea trypsin inhibitor) inhibited serine proteinases from larvae of tomato moth (Lacanobia oleracea) (Gatehouse et al. 1999).

It is likely that the consumption of CaTI led to the overproduction of sulfur-deficient primary larval proteolytic enzyme, which was detrimental to larval health (Headey et al. 2010). It has been reported that serine proteinase inhibitor $\mathrm{KTi}_{3}$ from the soybean resulted in up to $100 \%$ mortality of first instar Spodoptera littoralis (Schuler et al. 1998). Wu et al. (1997) reported a $13 \%$ decrease in total proteinase activity in $H$. armigera larvae, fed on transgenically expressed PI from giant taro. Moreover, Bown et al. (1997) also reported decrease in the overall level of proteinases and mRNAs encoding trypsin-like proteinases of $H$. armigera fed on soybean trypsin inhibitor (TI), suggesting that the decrease in activity was at transcriptional level. Parde et al. (2010) evaluated 22 different hosts and non-host plant protease inhibitors (PIs) for in vivo inhibition of Helicoverpa armigera gut pro- and proteinases. In vivo studies reported stunted growth of $H$. armigera larvae using non-host plant PIs, indicating the latter as good candidates for genetically engineered plants to confer resistance against H. armigera. Likewise, Saadati and Bandani (2011) reported a decrease in tryptic activity in digestive tract extracts from $H$. armigera larvae fed with SKTI.

Our results were concurrent with those by Wang and Qin (1996) and Johnston et al. (1993), as soybean kunitz type trypsin inhibitor and soybean BowmanBirk type trypsin-chymotrypsin inhibitor both showed reduction in the larval weight of $H$. armigera in trypsin inhibitor amended diet. Gomes et al. (2005) observed a $45 \%$ mortality rate when $1.5 \%(\mathrm{w} / \mathrm{w})$ of chickpea trypsin inhibitor was fed to Anthonomus grandis larvae, and a 33\% mortality rate of $H$. armigera was observed in feeding mung bean TI impregnated diet. Similar insecticidal response against Spodoptera litura (Fabricus) was observed using protease inhibitor from leaves of Coccinia grandis (L.) Voigt. (Satheesh and Murugan 2012).

By gathering the present and previously reported data (Kansal et al. 2008), it appears that CaTI acts as an antimetabolite and has an insecticidal property, since it works on the insect's intestinal tract or interferes with digestion. We may interpret that the use of trypsin inhibitor to protect plants against insect pests is complicated due to the ability of insects to circumvent plant defenses. Thus, the action of CaTI on the development of H. armigera indicates its detrimental potential as it significantly increased mortality. The defensive activity may be related to the presence of a large number of trypsin-like proteases in their midgut. The results of in vitro trypsin inhibitory assay and ingestion studies revealed its antimetabolite activity as it affected both the growth and digestive physiology of $H$. armigera, leading to starvation and death.

Additional studies of CaTI in Central India concerning other insects are required to confirm the biotechnological potential of this inhibitor as an agent against phytophagus insects. As India is the largest chickpea producing country, therefore continuous efforts are carried out by 
J.N.K.V.V. and FBIPL to provide best seeds to farmers in the Jabalpur region. To sum up, CaTI can be used as a marker for generating resistant cultivars as future research should be addressed to using trypsin inhibitor for marker assisted selection.

\section{ACKNOWLEDGEMENTS}

The authors would like to thank the Head of the Department of Biological Sciences, Rani Durgavati University,
Jabalpur (India) for laboratory facilities and University Grant Commission Project (Govt. of India), New Delhi for financial assistance vide project no. UGC (32-370/2006) (SR) dated. 24/04/07. We would also like to thank the Head of the Department of Plant Breeding and Genetics for providing his excellent co-operation during the field studies carried out in J.N.K.V.V., Jabalpur fields. The author would also like to thank Mr. Sukhrat for his work in authenticating plant cultivars and for providing Helicoverpa armigera samples.

\section{REFERENCES}

Arumuganathan K, Earle ED (1991) Nuclear DNA content of some important plant species. Plant Molecular Biology Reporter 9:208-218.

Belew M, Eaker D (1976) The trypsin and chymotrypsin inhibitors in chickpeas. Identification of trypsin-reactive site, partial amino acid sequence and further physico chemical properties of the major inhibitor. European Journal of Biochemistry 62:499-508.

Bhattacharyya A, Babu CR (2009) Purification and biochemical characterization of a serine proteinase inhibitor from Derris trifoliata Lour. seeds: insight into structural and antimalarial features. Phytochemistry 70:703-12.

Bown DP, Wilkinson HS, Gatehouse JA (1997) Differentially regulated inhibitor sensitive and insensitive protease genes from the phytophagous insect pest, Helicoverpa armigera, are members of complex multigene families. Insect Biochemistry and Molecular Biology 27:625-638.

Chaturvedi I (2007) Economic threshold level and monitoring Systems: reality and practicality in Helicoverpa armigera (Lepidoptera: Noctuidae). Electronic Journal of Environmental, Agricultural and Food Chemistry 6:2199-2206.

De Leo F, Bonadé-Botino M, Ceci RL, Galerani R, Jouanin L (2001) Effects of mustard trypsin inhibitors expressed in different plants on three different lepidopteran pests. Insect Biochemistry and Molecular Biology31:593-602.

Dunse K, Anderson M (2011) Towards the Next Generation of Pest Resistant Plants. ISB News Report, Virginia Polytechnic Institute and State University June.

Ellis J, Jones D (1998) Structure and function of proteins controlling strain-specific pathogen resistance in plants. Current Opinion in Plant Biology 1:288-293.

Erlanger BF, Kokowesky N, Cohen W (1964) The preparation and properties of two new chromogenic substrates of trypsin. Archives of Biochemistry and Biophysics 95:271-278.
Gatehouse AMR, Norton E, Davison GM, Babbe SM, Newell CA, Gatehouse JA (1999) Digestive proteolytic activity in larvae of tomato moth, Lacanobia oleracea: Effects of plant proteinase inhibitor in vitro and in vivo. Journal of Insect Physiology 45:545-558.

Girard C, Le Metayer M, Bonade-Bottino M, Pham-Delegue $\mathrm{MH}$, Jouanin L (1998) High level of resistance to proteinase inhibitors may be conferred by proteolytic cleavage in beetle larvae. Insect Biochemistry and Molecular Biology 28:229-237.

Giri AP, Harsulkar AM, Deshpande VV, Sainani MN, Gupta VS, Ranjekar PK (1998) Chickpea defensive proteinase inhibitors can be inactivated by pod borer gut proteinases. Plant Physiology 116:393-401.

Giri AP, Kachole MS (1998) Amylase inhibitors of pigeonpea (Cajanus cajan L.) seeds. Phytochemistry 47:197-202.

Gomes A de PG, Dias SC, Jr Bloch C, Melo FR, Jr Furtado JR, Monnerat RG, Grossi-de-Sá MF, Franco OL (2005) Toxicity to cotton boll weevil Anthonomus grandis of a trypsin inhibitor from chickpea seeds. Comparative Biochemistry and Physiology, Part B: Biochemistry and Molecular Biology 140:313-9.

Harsulkar AM, Giri AP, Gupta VS, Sainani MN, Deshpande VV, Patankar AG, Ranjekar PK (1998) Characterization of Helicoverpa armigera gut proteinases and the interaction with proteinase inhibitors using gel $X$-ray film contact print technique. Electrophoresis 19:1397-1402.

Harsulkar AM, Giri AP, Kothekar VS (1997) Protease inhibitors of chickpea (Cicer arietinum L.) during seed development. Journal of the Science of Food and Agriculture 74:509-512.

Harsulkar AM, Giri AP, Patankar AG, Gupta VS, Sainani MN, Ranjekar PK, Deshpande VV (1999) Successive use of non-host plant proteinase inhibitors required for effective inhibition of Helicoverpa armigera gut proteinases and larval growth. Plant Physiology 121:497-506. 
Headey SJ, Macaskill UK, Wright MA, Claridge JK, Edwards PJ, Farley PC, Christeller JT, Laing WA, Pascal SM (2010) Solution structure of the squash aspartic acid proteinase inhibitor (SQAPI) and mutational analysis of pepsin inhibition. Journal of Biological Chemistry 285:27019-25.

Jibson MD, Birk Y, Bewley TA (1981) Circular Dichroism spectra of trypsin and chymotrypsin complexes with Bowman-Birk or chickpea trypsin inhibitor. International Journal of Protein Research 18:26-32.

Johnston KA, Gatehouse JA, Anstee JH (1993) Effects of soybean protease inhibitors on the growth and development of larval Helicoverpa armigera. Journal of Insect Physiology 39:657-664.

Johnston KA, Lee M, Gatehouse JA, Anstee JH (1991) The partial purification and characterization of serine proteinase activity in midgut of larval Helicoverpa armigera. Insect Biochemistry 21:389-397.

Kakade ML, Rackis JJ, McGhee JE, Puski G (1974) Determination of trypsin inhibitor activity of soy products: A collaborative analysis of an improved procedure. Cereal Chemistry 51:376-382.

Kansal R, Kumar M, Kuhar K, Gupta RN, Subrahmanyam B, Koundal KR, Gupta VK (2008) Purification and characterization of trypsin inhibitor from Cicer arietinum L. and its efficacy against Helicoverpa armigera. Brazilian Journal of Plant Physiology 20:313-322

Koiwa H, Shade RE, Zhu-Salzman K, Subramanian L, Murdock LL, Nielsen SS, Bressan RA, Hasegawa PM (1998) Phage display selection can differentiate insecticidal activity of soybean cystatins. Plant Journal 14:371-379.

Lawrence PK, Koundal KR (2002) Plant protease inhibitors in control of phytophagous insects. Electronic Journal of Biotechnology 5:5-6

Lee $\mathrm{SI}$, Lee $\mathrm{SH}$, Koo JC, Chun $\mathrm{HJ}$, Lim CO, Mun JH, Song YH, Cho MJ (1999) Soybean Kunitz trypsin inhibitor (SKTI) confers resistance to the brown planthopper (Nilaparvata lugens Stal.) in transgenic rice. Molecular Breeding 5:1-9.

Lowry OH, Rosenbrough NJ, Farr A, Randall RJ (1951) Protein measurement by folin phenol reagent. Journal of Biological Chemistry 193:265-267.

Maiti RK (2001) The Chickpea crop. In: Maiti R, Wesche-Ebeling P (eds), Advances in Chickpea Science, pp.1-32. Science Publishers Inc., Enfield, $\mathrm{NH}$.

Mulimani VH, Kulkarni S, Giri AP (2002) Detection of Legume Protease Inhibitors by the Gel-X-ray Film Contact Print Technique. Biochemistry and Molecular Biology Education 30:40-44.

Nagashima Y, Takeda M, Ohta I, Shimakura K, Shiomi K (2004) Purification and properties of proteinaceous trypsin inhibitors in the skin mucus of pufferfish Takifugu pardalis. Comparative Biochemistry and Physiology, Part B: Biochemistry and Molecular Biology 138:103-10.

Parde VD, Sharma HC, Kachole MS (2010) In vivo inhibition of Helicoverpa armigera gut pro-proteinase activation by nonhost plant protease inhibitors. Journal of Insect Physiology 56:1315-24
Prasad ER, Dutta-Gupta A, Padmasree K (2010) Purification and characterization of a Bowman-Birk proteinase inhibitor from the seeds of black gram (Vigna mungo). Phytochemistry $71: 363-72$

Rai S, Aggarwal KK, Babu CR (2008) Isolation of a serine Kunitz trypsin inhibitor from leaves of Terminalia arjuna. Current Science 94:1509-1512.

Ryan CA (1990) Protease inhibitors in plants-genes for improving defenses against insects and pathogens. Annual Review of Phytopathology 28:425-449.

Saadati F, Bandani AR (2011) Effects of serine protease inhibitors on growth and development and digestive serine proteinases of the Sunn pest, Eurygaster integriceps. Journal of Insect Science 11:1-12.

Saini HS, Weder JKP, Knights EJ (1992) Inhibitor activities of chickpeas (Cicer arietinum L.) against bovine, porcine and human trypsin and chymotrypsin. Journal of the Science of Food and Agriculture 60:287-295.

Sastry MC, Murray DR (1987) The contribution of trypsin inhibitors to the nutritional value of chick pea seed protein. Journal of the Science of Food and Agriculture 40:253-261.

Satheesh LS, Murugan K (2012) Purification of protease inhibitor from leaves of Coccinia grandis (L.) Voigt. and its insecticidal potentiality against Spodoptera litura Fabricus. Asian Pacific Journal of Tropical Biomedicine 1:1-9.

Schuler TH, Poppy GM, Kerry BR, Denholm I (1998) Insect resistant transgenic plants. Trends in Biotechnology 16:168-175.

Sharma U, Suresh CG (2011) Purification, crystallization and X-ray characterization of a Kunitz-type trypsin inhibitor protein from the seeds of chickpea (Cicer arietinum). Acta Crystallographica -Structural Biology and Crystallization Communications 67:714-7.

Smirnoff P, Khalef S, Birk Y, Applebaum SW (1979) Trypsin and chymotrypsin inhibitor from chickpeas-selective chemical modification of the inhibitor and isolation of two isoinhibitors. International Journal of Protein Research 14:186-192.

Srinivasan A, Giri AP, Harsulkar AM, Gatehouse JA, Gupta VS (2005) A Kunitz trypsin inhibitor from chickpea (Cicer arietinum L.) that exerts anti-metabolic effect on podborer (Helicoverpa armigera) larvae. Plant Molecular Biology 57:359-74.

Thangwana NM, Ogola, JBO (2012) Yield and yield components of chickpea (Cicer arietinum): Response to genotype and planting density in summer and winter sowings. Journal of Food, Agriculture and Environment 10:710-715.

Vain P, Worland B, Clarke MC, Richard G, Beavis M, Liu H, Kohli A, Leech M, Snape J, Christou P (1998) Expression of an engineered cysteine proteinase inhibitor (Oryzacystatin-I delta D86) for nematode resistance in transgenic rice plants. Theoretical and Applied Genetics 96:266-271.

Valueva TA, Parfenov IA, Revina TA, Morozkina EV, Benevolensky SV (2012) Structure properties of the potato chymotrypsin inhibitor. Plant Physiology and Biochemistry $52: 83-90$ 
Nair et al.

Wang CZ, Qin JD (1996) Effect of soybean trypsin inhibitor gossypol, and tannic acid on the midgut protease activities and growth of Helicoverpa armigera larvae. Acta Entomologica Sinica 39:337-341.
Wu Y, Llewellyn D, Mathews A, Dennis ES (1997) Adaptation of Helicoverpa armigera (Lepidoptera: Noctuidae) to a proteinase inhibitor expressed in transgenic tobacco. Molecular Breeding 3:371-380 